Full length article

\title{
A study of the relationship between parental mediation and adolescents' digital skills, online risks and online opportunities
}

\author{
Isabel Rodríguez-de-Dios ${ }^{\mathrm{a},}$ *, Johanna M.F. van Oosten ${ }^{\mathrm{b}}$, Juan-José Igartua ${ }^{\mathrm{a}}$ \\ a University of Salamanca, Faculty of Social Sciences, Avenida Francisco Tomás y Valiente S/n, Campus Unamuno (Edificio FES), 37007 Salamanca, Spain
}

${ }^{\mathrm{b}}$ University of Amsterdam, Amsterdam School of Communication Research (ASCoR), Postbus 15791, 1001 NG, Amsterdam, The Netherlands

\section{A R T I C L E I N F O}

\section{Article history:}

Received 14 September 2017

Received in revised form

10 January 2018

Accepted 14 January 2018

Available online 17 January 2018

\section{Keywords:}

Digital skills

Adolescents

Parental mediation

Online risks

Online opportunities

Scale validation

\begin{abstract}
A B S T R A C T
In recent years, discussions have sparked about the risks and opportunities that digital technologies may have for adolescents. Some researchers argue that the best way to increase online opportunities and avoid online risks is to increase adolescents' digital skills. For this reason, the first goal of this study was to examine how adolescents' digital skills are related to their online opportunities and online risks behaviours. A second goal was to examine the influence of two ways of parental mediation (active and restrictive) on the level of teenagers' digital skills, and subsequently their online opportunities and online risks. Finally, we intended to establish the validity and the structure of the Digital Literacy Scale. Using data from a cross-sectional survey of 1.446 Spanish secondary school pupils, we found that more digitally skilled adolescents take more opportunities, and experience more risks. Digital literacy mediates the relationship between restrictive (but not of active) parental mediation and online risks and opportunities. Furthermore, the Digital Literacy Scale was shown to be valid in terms of construct validity. The findings suggest that digital literacy remains essential as it lets teenagers take more opportunities, and that parents should opt for other ways of mediation rather than restrictive mediation.
\end{abstract}

(C) 2018 Elsevier Ltd. All rights reserved.

\section{Introduction}

Nowadays, digital technologies, such as computers and smartphones, are present in all areas of our lives. We use them to communicate, study, work, learn and also to entertain ourselves. In addition, children who are born in this digital environment learn to speak, read or even walk at the same time as they learn to use digital devices. Young people are at the forefront of using digital technologies and there are very few who do not use them. In fact, 93\% of European adolescents (94\% in the case of Spain) use the Internet at least weekly, and most of them connect to the Internet daily (Eurostat, 2016).

Although adolescents are usually at the forefront of digital technologies and are recognised as digital natives, we cannot automatically consider them digitally literate (Li \& Ranieri, 2010; Margaryan, Littlejohn, \& Vojt, 2011). Research shows that adolescents have difficulties in finding, managing and evaluating information, managing their privacy online and ensuring their online

\footnotetext{
* Corresponding author.

E-mail addresses: isabelrd@usal.es (I. Rodríguez-de-Dios),j.m.f.vanoosten@uva. nl (J.M.F. van Oosten), jigartua@usal.es (J.-J. Igartua).
}

personal safety (Calvani, Fini, Ranieri, \& Picci, 2012; Livingstone \& Helsper, 2010; van Deursen \& van Diepen, 2013), and may thus vary in their digital skills. For this reason, many researches have been concerned about the consequences that living in an increasingly digitized world may have for children and adolescents (Patchin \& Hinduja, 2010; Staksrud, Ólafsson, \& Livingstone, 2013; Teimouri et al., 2014). More specifically, it is a matter of concern whether minors develop the skills that are needed to function effectively in this environment, to take advantage of the greater number of online opportunities and to avoid online risks, such as contact with strangers and cyberbullying. Moreover, previous research has shown that parents play an important role in guiding children in the appropriate types of media use to reduce negative consequences, through parental mediation (Bersamin et al., 2008; Buijzen \& Valkenburg, 2005). However, when it comes to digital technologies, little is known about how parents can guide their children in developing digital skills.

Therefore, the present study had three goals. First, we examined if adolescents' digital skills are related to more online opportunities and less online risks. Second, we aimed to study whether adolescents' digital skills mediate the relationship between parental mediation and adolescents' online risks and opportunities. Third, 
given the lack of a validated quantitative measure of digital skills, we assess the validity of the recently developed Digital Literacy Scale.

\section{Theoretical background}

\subsection{Defining digital literacy and digital literacy skills}

In the last few years, research related to digital literacy and digital skills has grown exponentially. The ongoing development of digital devices and their presence in our daily lives make digital skills essential in a range of professional occupations, for different aspects of people's lives and for being successful in our society (Bunz, Curry, \& Voon, 2007; Vandoninck, D'Haenens, \& Donoso, 2010). The first definitions of digital literacy referred only to an instrumental knowledge of hardware and software. Nowadays, scholars go beyond this approach and also stress the importance of knowing how to use digital devices in a social context (Bawden, 2002; Gutiérrez, 2003). Some scholars consider digital literacy as the ability to efficiently and accurately use digital information technologies and the information retrieved from them in a variety of contexts (Riel, Christian, \& Hinson, 2012, pp. 1-22). Moreover, according to Süss (2001), digital literacy consists of using a new medium so that it provides advantages over other forms of learning and, at the same time, being critical and aware of the impact of that environment on oneself. Although these definitions of digital literacy have slight differences in their scope or focal areas, their meanings actually overlap (Zhang \& Zhu, 2016).

Moreover, digital literacy shares conceptual grounds with other types of literacy, such as information literacy (i.e., the ability to identify, locate, evaluate and use information (Thompson, 2003),), media literacy i.e., the ability to access, understand and critically evaluate media messages, (Koltay, 2011), and news media literacy i.e., the ability to apply core media literacy skills to news (Vraga, Tully, Kotcher, Smithson, \& Broeckelman-post, 2015), (Maksl, Craft, Ashley, \& Miller, 2017). Therefore, digital literacy includes elements of other literacies, so that even some authors state that it is composed by other literacies (Koltay, 2011). For example, many classifications of the skills that comprise digital literacy include an informational skill (Eshet-Alkalai, 2004; Sonck \& de Haan, 2014), that refers to the ability to identify, locate, evaluate and use information in the digital environment. In the same way, the dimension media locus of control of the News Media Literacy Scale (Maksl, Ashley, \& Craft, 2015) would be related to the critical dimension in digital literacy. Obviously, there are considerable differences between these types of literacy. We could say that media literacy tries to develop critical consumers of media; news media literacy, critical consumers of news content; information literacy, users competent in finding and selecting information; and digital literacy, critical, safe and independent users of digital media.

In view of the above, we rely on the following definition of digital literacy, as we consider that it reflects all previous conceptualizations and related forms of literacy and can be applied for new digital environments (such as social networking sites):

"Digital literacy is the awareness, attitude and ability of individuals to appropriately use digital tools and facilities to identify, access, manage, integrate, evaluate, analyse and synthesize digital resources, construct new knowledge, create media expressions, and communicate with others, in the context of specific life situations, in order to enable constructive social action; and to reflect upon this process" (Martin, 2005, p. 135).

Moreover, and based on previous literature (Bawden, 2001;
Claro et al., 2012; Eshet-alkalai \& Chajut, 2009; Gui \& Argentin, 2011; Hargittai, 2008; Helsper \& Eynon, 2013; Koc \& Barut, 2016; Lee \& Chae, 2012; Leung \& Lee, 2012a; Livingstone, 2004; Sonck \& de Haan, 2014; Wilson, Scalise, \& Gochyyev, 2015; Zhang \& Zhu, 2016), we consider that digital literacy consists of several specific digital skills that adolescents need to learn in order to function effectively in the digital environment.

In the present study we aim to check the validity and the structure of the Digital Literacy Scale that was previously developed (Rodríguez-de-Dios, Igartua, \& González-Vázquez, 2016), based on research by Area and Pessoa (2012), Shapiro and Hughes (1996), and Cabero, Marín, and Llorente (2012). In this scale, six different skills were considered as being part of the broader concept of digital literacy, similar to previous research (Bunz, 2004; Helsper \& Eynon, 2013; Lee \& Chae, 2012; Sonck \& de Haan, 2014; Zhang \& Zhu, 2016): technological or instrumental skills (i.e., the ability to effectively use digital technologies), communication skills (i.e., the ability to communicate through digital technologies), information skills (i.e., the ability to find information, obtain it, and evaluate its relevance in the digital environment), critical skills (i.e., the ability to critically analyse the information obtained), personal security skills (i.e., the ability to manage privacy online and ensure personal safety) and devices security skills (i.e., the ability to take precautions to keep digital devices safe and avoid potential threats, such as viruses and spyware).

\subsection{The role of digital literacy skills in online risks and opportunities}

When adolescents access the digital world, they might be exposed to potential online risks, such as cyberbullying, exposure to pornography and/or violence, sexting and contact with strangers (Livingstone, Haddon, Görzig, \& Ólafsson, 2011; Rodríguez-de-Dios \& Igartua, 2016; Ólafsson, Livingstone, \& Haddon, 2013). These terms are conceptualized as online risks because they are associated with a certain likelihood and magnitude of harm. That is, they carry the chance that adolescents might have a negative experience (Livingstone, 2013; Sonck \& de Haan, 2013).

Several studies have found a relationship between the above mentioned online risks and psychological consequences among adolescents, such as anxiety, depression, feelings of anger and frustration, stress, sleep disturbance and irritability among those who had suffered from cyberbullying (Dehue, Bolman, \& Völlink, 2008; Nixon, 2014; Schneider, O'Donnell, Stueve, \& Coulter, 2012). Similarly, online harassment has been related to distress and eating disorders (Gati, Tényi, Túry, \& Wildmann, 2002; Ybarra, Mitchell, Wolak, \& Finkelhor, 2006). Moreover, exposure to sexually explicit online material is related to outcomes that are potentially harmful for adolescents' sexual development, such as the endorsement of recreational attitudes toward sex, notions of women as sex objects, body dissatisfaction, stimulation of sexual preoccupancy and reduction of sexual satisfaction (Peter \& Valkenburg, 2006, 2007, 2008, 2009, 2014). Finally, and with reference to exposure to online violence, research has shown that violent media exposure is a risk factor for aggression (Bender, Plante, \& Gentile, 2018). Specifically, exposure to online violence is a significant predictor of violent behaviour, along with other risk factors such as substance use or having delinquent peers (Ybarra et al., 2008).

It is assumed that adolescents can avoid negative consequences of digital technologies by acquiring digital skills (Rodríguez-deDios \& Igartua, 2016; Sonck \& de Haan, 2014; Sonck, Livingstone, Kuiper, \& de Haan, 2011). Thus, some scholars suggest that digital skills could be a prevention tool against online risks, taking into 
consideration the good results obtained by media literacy in addressing the harmful effects of mass media (Duran, Yousman, Walsh, \& Longshore, 2008; Halliwell, Easun, \& Harcourt, 2011; Irving, Dupen, \& Berel, 1998; Jeong, Cho, \& Hwang, 2012). However, there are very few empirical studies that examine the relationship between digital skills and online risks (Sonck \& de Haan, 2014) and, contrary to what is expected, initial evidence suggests that the more skilled adolescents are, the more online risks they experience (Lee \& Chae, 2012; Leung \& Lee, 2012b; Livingstone et al., 2017b; Livingstone \& Helsper, 2010; Sonck \& de Haan, 2013; Staksrud et al., 2013).

At the same time, it has been argued that discussions about adolescents and digital technologies should not only focus on online risks, but also need to take online opportunities into account (Livingstone, Mascheroni, \& Staksrud, 2017a). Digital technologies offer a broad range of opportunities for entertainment, communication, information and education that teenagers can take advantage of (Chisholm, 2006; Ktoridou, Eteokleous, \& Zahariadou, 2012; Livingstone \& Helsper, 2010; Vandoninck et al., 2010). For instance, online communication can enhance online self-disclosure, that is, online communication about personal topics that are typically not easily disclosed, such as one's feelings, worries, and vulnerabilities, which in turn can promote adolescents' well-being (Valkenburg \& Peter, 2009) and social relationships (Koutamanis, Vossen, Peter, \& Valkenburg, 2013). Moreover, research has shown that social media use can be beneficial for the development of empathic skills in adolescents (Vossen \& Valkenburg, 2016). There is also a link between playing online video games or computer games and having higher self-reported problem solving skills (Adachi \& Willoughby, 2013) and an increase in the speed and attention in mathematical calculations (Mahmoudi, Koushafar, Saribagloo, \& Pashavi, 2015). Furthermore, Jackson et al. (2006) concluded that low-income children who used the Internet more had greater reading achievement.

Regarding digital skills, it is suggested that more digitally skilled teenagers will take better advantage of the multiple options offered by online media. However, research has usually focused on the relationship between digital skills and online risks, with fewer studies analysing the role of these skills in promoting online opportunities. In any case, research suggests that those who have more internet skills or digital skills benefit more from online opportunities (Lee \& Chae, 2012; Livingstone \& Helsper, 2010; Nikken \& Schols, 2015; Sonck \& de Haan, 2013). It is therefore important to study the impact that digital skills can have on both online risks and opportunities $^{1}$ since finding the right balance between accessing online opportunities and experiencing online risks remains a challenge (Vandoninck et al., 2010).

\subsection{The role of digital skills in parental mediation of online risks and opportunities}

Scholars have acknowledged the role of parents in influencing and regulating adolescents' behaviours (Dornbusch, Ritter, Leiderman, Roberts, \& Fraleigh, 1987; Miller, 2002; Steinberg \& Morris, 2001). More specifically, the concept of parental mediation has been extensively studied within the field of children and adolescents' media use. Parental mediation consists of "the diverse practices through which parents try to manage and regulate their

\footnotetext{
${ }^{1}$ Consistent with previous research in this field (Helsper \& Eynon, 2013; Lee, 2012; Lee \& Chae, 2012; Livingstone et al., 2017b; Livingstone \& Helsper, 2010; Sasson \& Mesch, 2014; Sonck \& de Haan, 2013, 2014), we decided to conceptualize the different dimensions of online risks or online opportunities as one concept (online risks/online opportunities).
}

children's experiences with the media" (Livingstone, Mascheroni, Dreier, Chaudron, \& Lagae, 2015, p. 7). According to the literature, there are two major forms of parental mediation: active or instructive, and restrictive (Chen \& Chng, 2016; Kirwil, 2009; Shin, Huh, \& Faber, 2012). Active mediation takes place when parents talk to their child about the use of digital media and provide them with guidance and advice (Chen \& Chng, 2016) ÑN. Restrictive mediation refers to the regulation of online activities through the use of rules, such as controlling adolescents' time spent online (Chen \& Chng, 2016; Valcke, De Wever, Van Keer, \& Schellens, 2011). Traditionally, parental mediation of media, such as television, included a third form: co-viewing. However, in the case of digital media, this option is less feasible due to physical constraints, such as the necessity to share a device, and the fact that shared use without any discussion is less likely (Valkenburg, Piotrowski, Hermanns, \& de Leeuw, 2013).

Parental mediation has been generally considered as a useful strategy for risk prevention (Álvarez, Torres, Rodríguez, Padilla, \& Rodrigo, 2013). For instance, active mediation can diminish positive attitudes about pornography among adolescents (Rasmussen, Ortiz, \& White, 2015) and media's effects on adolescents' use of alcohol (Austin, Pinkleton, \& Fujioka, 2000). Overall, active mediation works better than restrictive mediation in reducing these risks (Duerager \& Livingstone, 2012; Khurana, Bleakley, Jordan, \& Romer, 2015; Lwin, Stanaland, \& Miyazaki, 2008; Shin \& Kang, 2016) and restrictive mediation is both positively and negatively associated with online risks (Khurana et al., 2015; Lau \& Yuen, 2013; Lee, 2012; Lee \& Chae, 2012; Liau, Khoo, \& Hwaang, 2005; Livingstone et al., 2017b; Mitchell, Finkelhor, \& Wolak, 2003; Sasson \& Mesch, 2014; Shin \& Ismail, 2014; Shin \& Kang, 2016).

Notwithstanding, some researchers argue that instead of worrying about online risks, parents should plan strategies for increasing children's positive use of the Internet (Daud, Omar, Hassan, Bolong, \& Teimouri, 2014). As said previously, scholars have tended to be concerned primarily with the negative effects of media (Clark, 2011), although digital media provide adolescents with many opportunities for entertainment, communication and education. In this sense, parental restrictions may reduce online risks at the expense of the opportunities (Lee \& Chae, 2012). For this reason, it is essential to analyse the parental mediation's relationship with online opportunities. According to the literature, active mediation is positively associated with children's online opportunities (Ihmeideh \& Shawareb, 2014; Livingstone et al., 2017b), while restrictive mediation is associated with fewer opportunities (Daud et al., 2014; Livingstone et al., 2017b).

In addition to online risks and opportunities, researchers have recently also started to be concerned with the impact that parental mediation could have on adolescents' digital skills (Valcke, Bonte, De Wever, \& Rots, 2010; Zhang \& Zhu, 2016). Since parents play an important role in their children's learning, it is relevant to analyse whether parents' mediation of adolescents' use of digital media has any influence on the development of digital skills. Some authors consider parental mediation as a key strategy in developing minors' skills for using and interpreting the media, and for promoting positive outcomes while preventing negative effects of media (Nikken \& Schols, 2015). Even so, empirical studies in this field are still very scarce. Two studies have shown a relationship between parental mediation and the digital literacy of children. However, one of these studies does not distinguish between different types of parental mediation (Nikken \& Schols, 2015) and the other only measures digital skills through the parents' perceptions (Zhang \& Zhu, 2016). Some scholars suggest that child reports are more reliable when it comes to measuring their skills (Fujioka \& Weintraub Austin, 2003; Nathanson, 2001; Symons, 
Ponnet, Emmery, Walrave, \& Heirman, 2017). There is only one study that has focused on parental mediation and digital skills among adolescents, and it concludes that active mediation is related to an increase in digital skills, whereas restrictive mediation reduces these skills (Duerager \& Livingstone, 2012). Consequently, more research is needed to clarify the impact of parental mediation on adolescents' digital literacy.

Furthermore, previous research has investigated direct relationships between parental mediation, and either digital skills, online risks or online opportunities. However, previous research shows that a) parental mediation may influence adolescents' digital skills, and that b) adolescents' digital skills influence online risks and opportunities. Hence, it can be expected that digital skills mediate the relationships between parental mediation and online risks and online opportunities.

Nonetheless, no study to date has investigated such an indirect relationship within the same study. Therefore, in this study we will not only look at the influence of digital literacy on online risks and online opportunities, but also how this construct mediates the relationship between parental mediation and risks and opportunities. Against this backdrop, we will test a model that shows the relationship between parental mediation, digital literacy, online risks and online opportunities (see Fig. 1).

In this model, digital literacy is hypothesized to be a positive predictor of online risk behaviours (H1a) and online opportunities (H1b). Moreover, active parental mediation is hypothesized to be positive predictor of teenagers' digital literacy (H2a), whereas restrictive parental mediation is hypothesized to be negatively related to digital literacy $(\mathrm{H} 2 \mathrm{~b})$. Finally, we expect that digital literacy will mediate the relation between parental mediation and online risks and online opportunities (H3). Therefore, active parental mediation is expected to increase both online risks and online opportunities by increasing digital skills. On the contrary, restrictive mediation is expected to decrease online risks and online opportunities by decreasing digital skills.

\subsection{Validating digital literacy measures among adolescents}

In order to study people's digital skills, researchers have started to develop digital literacy measures. However, currently existing measures have several limitations, such as not being up to date with the fast changes in technology (Wilson et al., 2015), having a narrow focus on the Internet at the omission of other technological developments (Hargittai \& Hsieh, 2012; Lee \& Chae, 2012; Len-Ríos, Hughes, McKee, \& Young, 2016; Tsai \& Tsai, 2010) or not having been validated (Pino Juste \& Soto Carballo, 2010; Gastelú, Kiss, \& Domínguez, 2015; Li \& Ranieri, 2010; Park \& Burford, 2013). Others have been validated only among children, adults or young adults, but not among adolescents (Boyaci \& Atalay, 2016; Bunz et al., 2007; Helsper \& Eynon, 2013; Koc \& Barut, 2016; Park \&
Burford, 2013; Røkenes \& Krumsvik, 2016). Consequently, one of the subgoals of this study is to check the construct validity of the Digital Literacy Scale that was previously developed (Rodríguez-deDios et al., 2016) among a sample of Spanish adolescents.

\section{Methods}

\subsection{Sample and procedure}

From March to May 2016, a survey was conducted among 1.446 Spanish pupils of secondary education (49\% boys) between 12 and 18 years of age $(M=13.9, S D=1.28)$. Data were collected at thirteen Spanish schools in both rural (seven schools) and urban (six schools) areas of Spain (51\% respondents from a rural school). Students completed a paper-and-pencil questionnaire under the supervision of a researcher and a teacher during class. The survey took about 15-30 min to complete and it contained measures of parental mediation, digital literacy, online risk behaviours, online opportunities, positive ICT attitude and technology anxiety (as convergent validation measures), as well as other variables not of interest for the current study. We used a self-report questionnaire, which is the most frequently used method for measuring digital skills (Kuhlemeier \& Hemker, 2007). Some researches argue that, ideally, digital skills should be directly observed in performance tests (Sonck \& de Haan, 2013), but their costliness and timeconsumption are strong limitations (van Deursen, van Dijk, \& Peters, 2012). Therefore, self-report questionnaires are unquestionably useful when we want to deal with large samples in a short time. Informed consent was received from school staff (school principals and heads of studies) and the corresponding Provincial Education Directorate.

\subsection{Measures}

\subsubsection{Parental mediation}

Parental mediation was assessed using twelve items adapted from previous studies (Khurana et al., 2015; Martínez, Cortés, Medrano, \& Apodaca, 2014; Sasson \& Mesch, 2014). Five of these twelve items were designed to measure restrictive parental mediation, whereas seven items were developed for assessing active or instructive parental mediation. Many scholars have shown disagreement between parents and children in reporting parental mediation (Baxter, Bylund, Imes, \& Routsong, 2009; Buijzen, Rozendaal, Moorman, \& Tanis, 2008; Vaterlaus, Beckert, Tulane, \& Bird, 2014). Therefore, some of them suggest investigating both parents and children. However, this "can be time-consuming and expensive, and the question remains how to treat such complex family data" (Buijzen et al., 2008, p. 523). For that reason, some scholars recommend using child reports of parental mediation as they are more reliable predictors of the mediation outcome

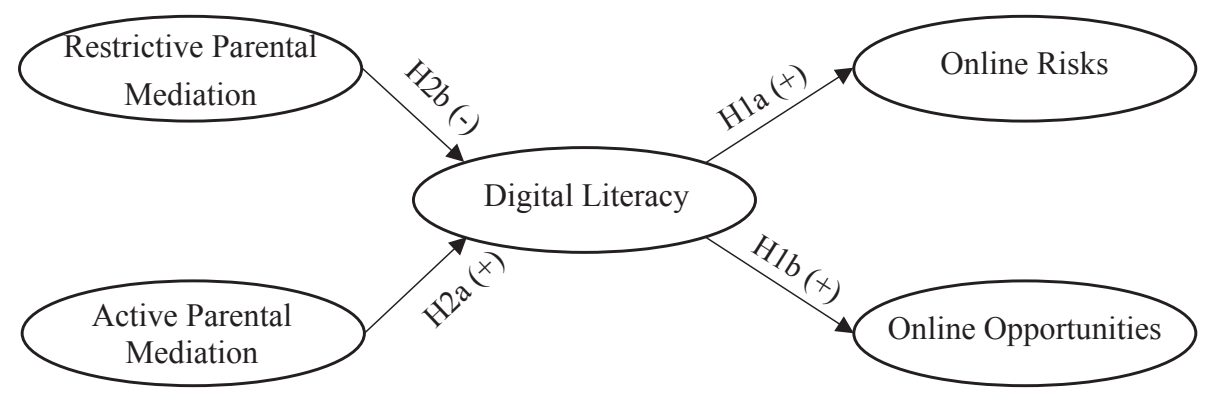

Fig. 1. Relationship between parental mediation, digital literacy and online risks and online opportunities. 
(Fujioka \& Weintraub Austin, 2003; Nathanson, 2001).

On a scale ranging from (1) Never to (5) Always, adolescents reported on how often their parents engage in certain regulatory behaviours of their media use (e.g. "restrict the amount of time you spend online" (restrictive mediation) or "explain why some websites are good or bad" (active or instructive mediation)). Exploratory factor analyses (EFA) revealed that these items, with factor loadings above 0.50 , loaded on the two latent factors previously proposed, that accounted for $58 \%$ of the explained variance (EV): Restrictive parental mediation $(E V=22 \% ; \alpha=0.76 ; M=1.95$, $S D=0.80)$ and active parental mediation $(E V=36 \% ; \alpha=0.89$; $M=2.85, S D=1.10$ ). The means are based on the variables that were created by making a mean score of the separate items for each type of parental mediation.

\subsubsection{Digital literacy}

Six different digital skills were assessed with 29 items that were measured in a 5-point Likert scale of self-reported agreement, responses ranging from (1) Strongly disagree to (5) Strongly agree (see Appendix A). As also reported previously (Rodríguez-de-Dios et al., 2016), EFA revealed that these items loaded on six latent factors, that together accounted for $44 \%$ of the variance: technological skill $(E V=21.16 \% ; \alpha=0.73 ; M=3.80, S D=0.73)$, personal security skill $(E V=6.60 \% ; \alpha=0.73 ; M=3.93, \mathrm{SD}=0.81)$, critical skill $(E V=5.42 \% ; \alpha=0.75 ; M=3.38, S D=0.76)$, devices security skill $(E V=4.15 \% ; \alpha=0.72 ; M=3.23, S D=0.94)$, informational skill $(E V=3.96 \% ; \alpha=0.63 ; M=3.39, S D=0.69)$ and communication skill ( $E V=3.02 \% ; \alpha=0.46 ; M=3.70, S D=0.58$ ) (results of further validation of this scale will be discussed below in section 4.2). Mean scores are based on the variables that were created by taking the mean of the separate items.

\subsubsection{Online risk behaviours}

Eighteen items were developed, based on previous studies (Livingstone \& Helsper, 2010; Valcke et al., 2011; Álvarez-García, Dobarro, \& Núñez, 2015), for measuring online risks behaviours. On a scale ranging from (1) Never to (5) Always, adolescents reported on how often they engage in certain activities online (e.g. "Send personal pictures to people I meet online" or "Visit a porn site on purpose"). EFA revealed that these items loaded on five latent factors that accounted for $61 \%$ of the total explained variance: contact with strangers $(E V=15 \% ; \alpha=0.76 ; M=1.61, S D=0.64)$, exposure to pornography ( $E V=13 \% ; \alpha=0.80 ; M=1.40, S D=0.69$ ), exposure to violence $(E V=11 \% ; \alpha=0.67 ; M=1.25, S D=0.55)$, cyberbullying victim ( $E V=10 \% ; \alpha=0.66 ; M=1.16, S D=0.39)$ and cyberbullying perpetrator $(E V=11 \% ; \alpha=0.69 ; M=1.08, S D=0.34)$. Two items (i.e., "someone has pretended to be me on the Internet and publish things to do me harm"; "I send photos of myself naked or of my private parts") were deleted from the analysis because they have high loadings on more than one factor and thus were not clearly indicative of one of the five latent factors. Means are based on the variables that were created by making a mean score of the separate items. After a CFA, which confirmed that the five factors were related to a higher-order dimension, a latent variable (online risks) was created and included in the model.

\subsubsection{Online opportunities}

Following Vandoninck et al. (2010), we conceptualize online opportunities as the use of online applications, such as applications directed at communicating. In this sense, it is important to point out that the main difference between online risks and online opportunities is that online opportunities generally afford positive benefits for children, whereas online risks are associated with a certain likelihood of harm (Livingstone, 2013). In any case, online opportunities do not always imply benefit and, likewise, online risks do not always imply harm.

Eleven items on a 5-point Likert scale, being (1) never, (2) less frequently than the above, (3) 2-3 times per week, (4) once a day, (5) several times a day, were developed for measuring different online activities (e.g. "use photo or video editing software", "use instant messaging") (Vandoninck et al., 2010). EFA revealed the existence of three latent factors: Communication, that is, the use of applications directed at communicating, such as instant messaging or social networking sites, $(E V=20 \% ; \quad \alpha=0.53 ; \quad M=3.97$, $S D=0.67)$; Entertainment, use of applications directed at searching for entertainment, such as playing games or downloading games, $(E V=17 \% ; \alpha=0.74 ; M=2.84, S D=1.09)$; and Multimedia, use of applications related to multimedia, such as downloading films/ music or using photo or video editing software ( $E V=16 \%$; $\alpha=0.58$; $M=2.42, S D=0.93$ ). One item (i.e., "download apps") was deleted because it loaded on two factors. All the factors, which accounted for $53 \%$ of the total explained variance, were submitted to a CFA. As it showed that they were related to a higher-order dimension, only one latent factor (online opportunities) was included in the model.

\subsubsection{Convergent validity of digital literacy: positive ICT attitude and technology anxiety}

A review of the literature shows that there is a positive correlation between high levels of digital literacy and a favourable attitude towards technology (Gebhardt et al., 2012; Zylka, Christoph, Kroehne, Hartig, \& Goldhammer, 2015), and a negative association with anxiety towards technology (De Wit, Heerwegh, \& Verhoeven, 2014; Durndell \& Haag, 2002; Zylka et al., 2015). Thus, for examining the convergent validity of the Digital Literacy Scale we included a Positive Attitude towards Technology Scale and a Technology Anxiety Scale in the survey.

Positive ICT attitude was assessed using eleven items adapted from the literature (Fraillon, Ainley, Schulz, Friedman, \& Gebhardt, 2014; Ng, 2012; Wilkinson, Roberts, \& While, 2010) (e.g. "It is more fun to do homework using a computer than without it"). Items were measured on a 5-point Likert scale of agreement, from (1) strongly disagree to (5) strongly agree. All items loaded on the one factor, with factor loadings ranging from 0.40 to 0.77 and an explained variance of $39 \%(\alpha=0.84 ; M=3.57, S D=0.71)$.

Technology anxiety was measured with nine items on a 5-point Likert scale of agreement, from (1) strongly disagree to (5) strongly agree, which have been used to assess technology anxiety in previous studies (Barbeite \& Weiss, 2004; Heinssen, Glass, \& Knight, 1987) (e.g. "Computers make me feel uneasy and confused"). The nine items loaded on one factor with factor loadings ranging from 0.58 to 0.73 and an explained variance of $43 \%(\alpha=0.83 ; M=1.89$, $S D=0.68)$.

\subsection{Data analysis}

Data were analysed using SPSS 22 and AMOS 20. To examine cross-population validity, we randomly divided the data into two groups. The first sample had been previously used for conducting EFA to discover the latent digital skills. The internal consistency of these constructs was then checked with Cronbach's alpha. The convergent validity of the Digital Literacy Scale with the Positive Attitude towards Technology Scale and the Technology Anxiety scale was assessed using Pearson's correlation coefficient. Subsequently, the second sample was used for conducting Confirmatory Factor Analysis (CFA) on the Digital Literacy Scale with AMOS.

Finally, AMOS was used to test the hypotheses in a structural equation model using the entire sample. In this model, we used latent factors as indicators of the 3 s-order factors (digital literacy (six digital skills), online risks (five online risks) and online 


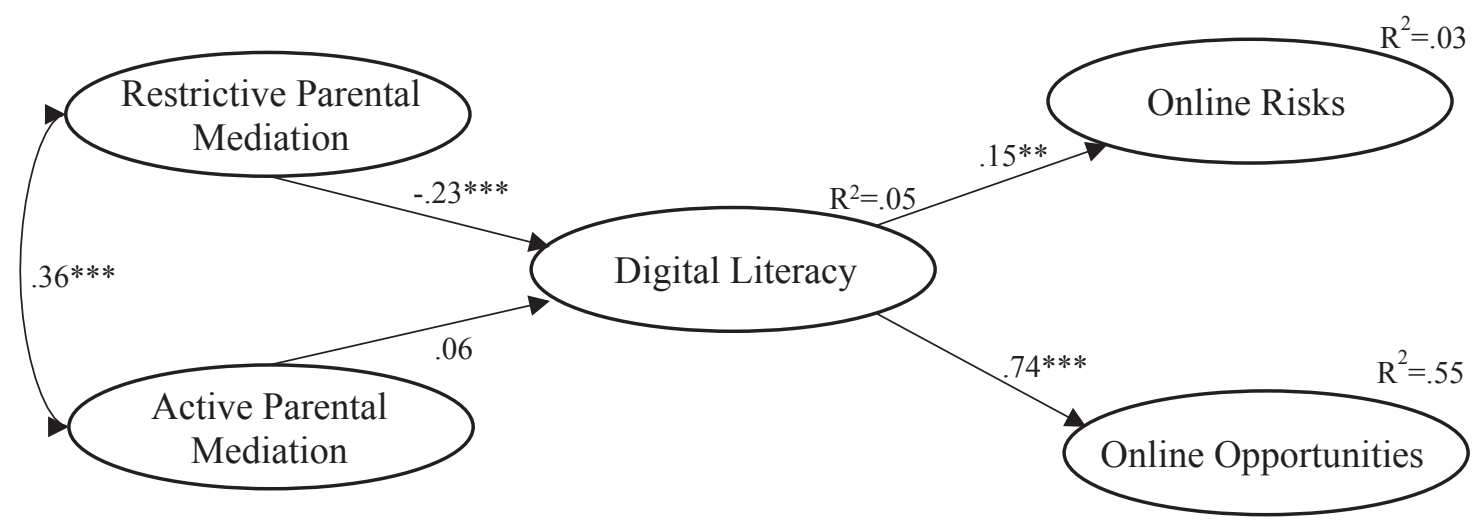

Fig. 2. Structural Equation Model with standardized estimates.

opportunities (three types of online opportunities)) and two latent constructs (restrictive mediation and active mediation). Moreover, only two latent constructs (restrictive and active parental mediation) were allowed to covary.

Given the fact that Shapiro-Wilk test showed that the variables failed to meet the normality assumption, a bootstrap method was used in both analyses with AMOS. We estimated $95 \%$ bias-corrected confidence intervals with 1.000 bootstrapping samples. In this context, an association is considered statistically significant if the confidence intervals (95\% BCI) do not include zero. Taking into consideration that a bootstrap method cannot be performed with missing data, missing values were replaced using the linear trend at point technique in SPSS. None of the variables had more than 3\% cases missing and most of them had missing data in less than $1 \%$ of the cases. Results were not affected neither by the replacement missing values nor by the bootstrap methods.

\section{Results}

\subsection{Testing the hypothesized model}

To test our hypotheses, a structural equation model was constructed using AMOS (Fig. 2). Both types of parental mediation (restrictive and active) were included as predictor variables of digital literacy. Concurrently, digital literacy was added as a

\footnotetext{
${ }^{2}$ Following the principle of parsimony, we developed the model with secondorder factors (digital literacy, online risks and online opportunities) (Brown, 2015; Chen, Sousa, \& West, 2005; Field, 2013; Hayes, 2005; Kline, 2013). We must highlight that a model without second-order factors and with manifest items loading on the latent factors was built for testing purposes. It produced a worse level of fit, X2 $(2018)=8528,7, \mathrm{p}<.001, \mathrm{CFI}=0.77, \mathrm{RMSEA}=0.05(90 \%[\mathrm{CI}]=[0.04$ $0.05])$, and it did not affect the core relationships being examined.

${ }^{3}$ In this respect, we should recall that values of RMSEA less than 0.05 are considered as indicative of close or good fit. However, values below 0.08 can also be accepted, as they suggest adequate fit, but models with a RMSEA greater than 0.1 should be rejected (Browne \& Cudeck, 1992; Kline, 2013). Other authors state that the upper limit should be less than 0.08 (Hooper, Coughlan, \& Mullen, 2008). Therefore, our RMSEA value indicates an acceptable, but not excellent, model fit. We should also note that RMSEA values, and especially confidence intervals, can increase because of a small sample size and a large number of estimated parameters (Brown, 2015). Literature provides little guidance and only general rules for determining the appropriate sample size in a SEM study (Brown, 2015). In any case, if we consider the general rule, our sample should have at least 10 cases per parameter estimated in the analysis. Nevertheless, some authors recommend 20 cases for each parameter estimated in the analysis (Kline, 2013). As we have 61 parameters estimated and a sample size of 715 respondents, we have a ratio of 11.7 participants to one parameter estimated. Therefore, our RMSEA value could have been affected by the large number of estimated parameters.
}

predictor of online risks and online opportunities. ${ }^{2}$ Results demonstrate a modest level of fit: $X^{2}(290)=1251,782, p<.001$, comparative fit index $(\mathrm{CFI})=0.84$, root mean square error of approximation $\quad($ RMSEA $)=.07^{3} \quad(90 \%$ confidence interval $[\mathrm{CI}]=[0.06,0.07]) \cdot{ }^{4}$

Hypothesis 1 predicted that digital literacy would be positive predictor of online risks (H1a) and online opportunities (H1b). The analysis suggested that digital literacy is positively related to online opportunities, $\quad \beta=0.74, \quad b=0.44, \quad S E=0.05, \quad p<.001 \quad(95 \%$ $\mathrm{BCI}=[0.558,0.916])$, and online risks, $\beta=0.15, b=0.08, S E=0.03$, $p=.004(95 \% \mathrm{BCI}=[0.004,0.269])$. Therefore, Hypothesis 1a and $1 \mathrm{~b}$ are supported.

Hypothesis $2 \mathrm{a}$ stated that active parental mediation would be positive predictor of teenagers' digital literacy. In contrast, Hypothesis $2 \mathrm{~b}$ predicted that restrictive parental mediation would be a negative predictor of digital literacy. The results showed that restrictive parental mediation is negatively related to the level of digital literacy, $\beta=-0.23, b=-0.25, S E=0.06, p<.001 \quad(95 \%$ $\mathrm{BCI}=[-0.333,-0.125])$, whereas active parental mediation has no relationship with it, $\beta=0.06, b=0.04, S E=0.03, p=.21 \quad(95 \%$ $\mathrm{BCI}=[-0.050,0.158])$. Thus, Hypothesis $2 \mathrm{a}$ is rejected, whereas Hypothesis $2 b$ is confirmed.

\subsubsection{Indirect relationships: digital literacy as a mediating variable}

Hypothesis 3 predicted that digital literacy would mediate the relation between parental mediation an online risks and online opportunities. Testing the indirect relationship between parental mediation and online risks and opportunities through digital literacy as a mediating variable (see Fig. 2), we found that active parental mediation does not indirectly predict online risks, $\beta=0.01$, $b=0.00, S E=0.00, p=.167(95 \% \mathrm{BCI}=[-0.005,0.036])$ or online opportunities, $\beta=0.04, b=0.02, S E=0.02, p=.298(95 \% \mathrm{BCI}=[-$ $0.041,0.120])$ through digital skills.

On the contrary, restrictive mediation is negatively related to both online risks, $\beta=-0.03, b=-0.02, S E=0.01, p=.025(95 \%$ $\mathrm{BCI}=[-0.075,-0.005])$ and online opportunities, $\beta=-0.17$, $b=-0.11, S E=0.05, p=.001(95 \% \mathrm{BCI}=[-0.270,-0.093])$ through digital literacy.

\footnotetext{
${ }^{4}$ Considering the presence of large modification indices, a model with error term correlations was tested. Nevertheless, there were no substantial differences between the two models. There was only a slight improvement of the fit: $X^{2}$ $(277)=869,408, \mathrm{p}<.001, \mathrm{CFI}=0.90, \mathrm{RMSEA}=0.05(90 \%[\mathrm{CI}]=[0.05,0.06])$. For this reason, and taking into account that some scholars reject this procedure (Hermida, 2015), we decided to retain the original model without error term correlations.
} 
To investigate the significance of the indirect relationships, we tested the model with the nested-model logic under two conditions: one model where the direct paths from parental mediation to online risks and online opportunities were allowed to vary, and one model in which these paths were constrained to zero. Since there is a non-significant difference between both model's fits, $\Delta \chi^{2}(2$, $N=715)=4.87, p=.09$, digital literacy fully mediates the effect of active and restrictive parental mediation on online risks and online opportunities. Therefore, Hypothesis 3 is partially supported as digital literacy mediates the relation between restrictive parental mediation and online risks and online opportunities.

\subsection{Construct validity of the Digital Literacy Scale}

\subsubsection{Confirmatory factor analysis}

With the aim of confirming the structural validity of the Digital Literacy Scale and establishing cross-population validity, CFA was performed in AMOS 20, using the second half of the data $(N=731)$ (see Fig. 3). Prior to this step, EFA had been conducted on the first half on the data $(N=715)$ and it revealed the existence of six latent factors (see methods section, but also see: Rodríguez-de-Dios \& Igartua, 2016): Technological skill, Personal Security Skill, Critical Skill, Devices Security Skill, Informational Skill and Communication Skill. The overall structure of the scale was tested using CFA with

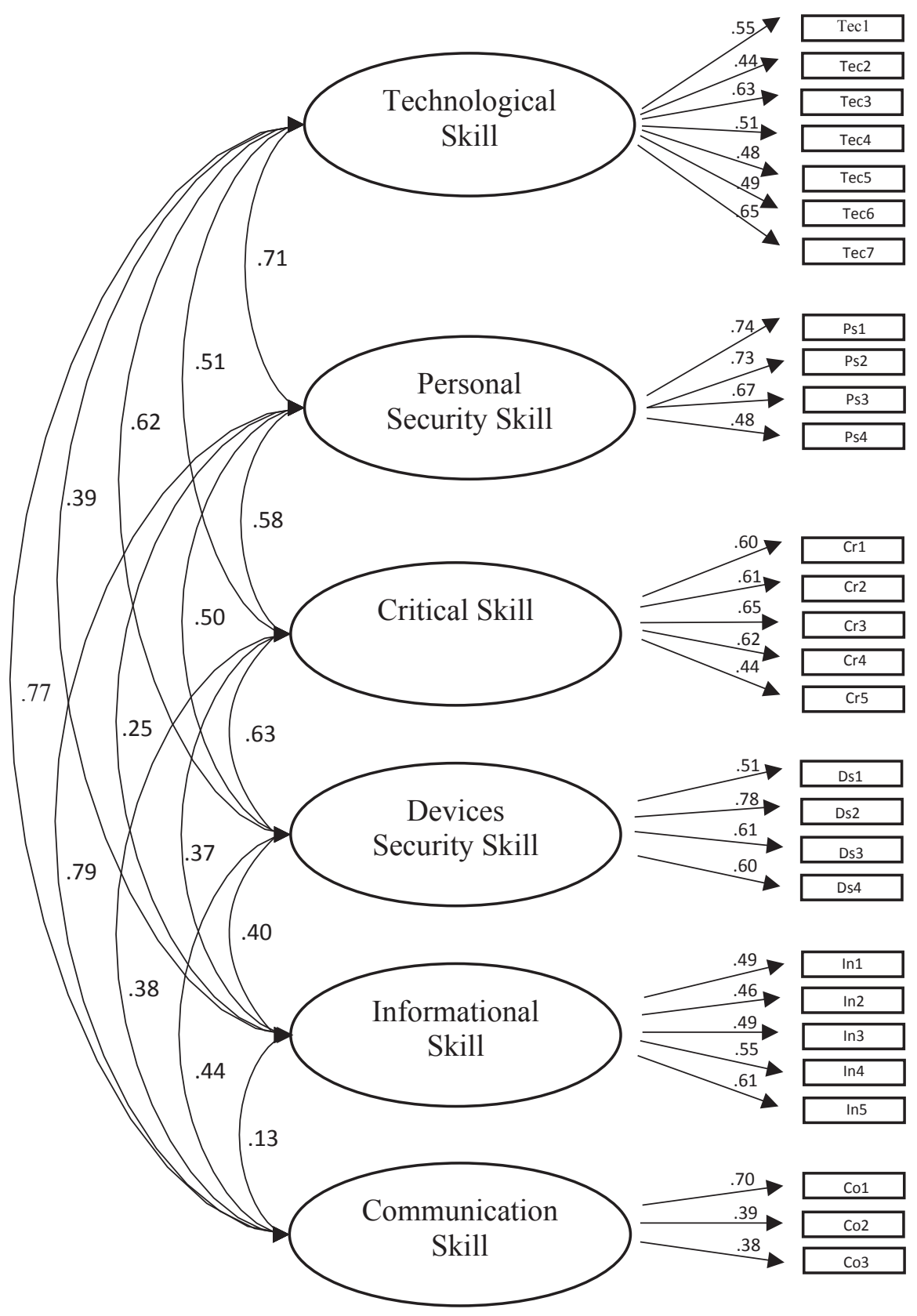

Fig. 3. Results of the confirmatory factor analysis. 
maximum likelihood estimation and the bootstrap method. In this process, one item (i.e., "I know the laws and consequences of illegal downloading of music and movies") was deleted due to its low factor loading (0.26) in the Personal Security Skill latent factor. The model fit was just short of the recommended criteria: $X^{2}$ $(335)=848.73, \quad p<.001, \quad C F I=0.89, \quad$ RMSEA $=0.046 \quad(90 \%$ $[\mathrm{CI}]=[0.04,0.05])^{5}$

\subsubsection{Convergent validity}

To examine the convergent validity, we correlated the different dimensions of the Digital Literacy Scale with the attitude to technology and technology anxiety (see Table 1). As we expected from the literature, a positive attitude to technology has significant positive correlations with the different digital skills. On the other hand, technology anxiety has negative correlations with digital skills Therefore, it could be argued that the scale is valid in terms of construct validity (Noar, 2003).

\subsubsection{Second-order confirmatory factor analysis}

Considering the significant correlation coefficients between all dimensions of skills (ranging from 0.134 to 0.789 ) a second-order CFA was conducted for confirming that they were related to a higher-order dimension. Therefore, the six latent factors were loaded into a second-order latent factor (Digital Literacy). Results suggested that the model fit was again slightly less than the recommended criteria: $X^{2}(344)=969.085, \quad p<.001, \quad C F I=0.87$, RMSEA $=0.05(90 \%[\mathrm{CI}]=[0.04,0.05]))^{6}$ Table 2 shows the standardized regression weights between the second-order factor (Digital Literacy) and the six first-order factors (Digital Skills), all of them statistically significant at the alpha level of 0.001 .

\section{Discussion}

Through this study, we aimed to examine the relationship between adolescents' digital skills and online risks and opportunities. As we hypothesized, and in consonance to previous studies, the more skilled teenagers are, the more online opportunities they take (Lee \& Chae, 2012; Livingstone \& Helsper, 2010; Nikken \& Schols, 2015; Sonck \& de Haan, 2013). Likewise, the more skilled adolescents are, the more online risks they experience (Lee \& Chae, 2012; Leung \& Lee, 2012b; Livingstone et al., 2017b; Livingstone \& Helsper, 2010; Sonck \& de Haan, 2013; Staksrud et al., 2013).

The second aim of the present study was to examine the influence of two types of parental mediation (active and restrictive) on the level of teenagers' online opportunities and online risks behaviours, indirectly through digital skills. We found that adolescents' digital literacy mediates the influence of restrictive, but not of active, parental mediation on online risks and opportunities. Restrictive parental mediation reduces adolescents' digital skills, and as such reduces both their online risks as well as online opportunities.

\subsection{Implications for research on digital skills and online risks and opportunities}

Digital skills positively predicted both online risks and online

\footnotetext{
${ }^{5}$ As in the other analysis, a model with error term correlations considering large modification indices was tested. In this case, the inclusion of correlations implied a slight improvement of the fit too: $X^{2}(332)=769.357, p<.001, C F I=0.91$, RMSEA $=0.04(90 \%[\mathrm{CI}]=[0.04,0.05])$

${ }^{6}$ The inclusion of error terms correlations in the second-order CFA implied also a slight improvement of the fit: $\mathrm{X}^{2}(341)=892.603, \quad p<.001, \quad \mathrm{CFI}=0.88$ RMSEA $=0.05(90 \%[\mathrm{CI}]=[0.04,0.05])$. Following the same criteria as described above, the original model without error term correlations was retained.
}

Table 1

Convergent validity: correlations.

\begin{tabular}{llll}
\hline & & Positive ICT attitude & Technology anxiety \\
\hline Digital Skills & Technological & $.51^{* * *}$ & $-.51^{* * *}$ \\
& Personal Security & $.34^{* * *}$ & $-.29^{* * *}$ \\
& Critical & $.31^{* * *}$ & $-.26^{* * *}$ \\
& Devices Security & $.39^{* * *}$ & $-.33^{* * *}$ \\
& Informational & $.14^{* * *}$ & $-.35^{* * *}$ \\
Digital literacy & Communication & $.14^{* * *}$ & $-.18^{* * *}$ \\
\hline
\end{tabular}

**** $p<.001$.

Table 2

Standardized regression weights.

\begin{tabular}{ll}
\hline & Digital Literacy \\
\hline Technological Skill & .876 \\
Personal Security Skill & .826 \\
Critical Skill & .660 \\
Devices Security Skill & .694 \\
Informational Skill & .401 \\
Communication Skill & .778 \\
\hline
\end{tabular}

opportunities. As adolescents spend more time online, they become more digitally literate, which may cause them to reap more benefits from digital technologies, in terms of communication, entertainment and multi-media purposes. Moreover, through these skills and these online opportunities adolescents would be able to avoid digital exclusion.

That becoming more digitally literate also increases the chances of experiencing online risks seems to be an unavoidable circumstance. At the same time, the associations between digital skills and online opportunities were stronger than those between digital skills and online risks. Likewise, digital skills did not explain much of the variance in online risks. This suggests that there may be other - and stronger - predictors of online risks. This also seems plausible when looking at the type of online risks measured in this study. Exposure to sexually explicit or violent content is predicted by many (offline) factors, such as personal interest and sensation seeking (Doornwaard, van den Eijnden, Baams, Vanwesenbeeck, \& ter Bogt, 2016; Doornwaard, van den Eijnden, Overbeek, \& ter Bogt, 2015; Slater, 2003), pubertal timing (Beyens, Vandenbosch, \& Eggermont, 2015), or peer norms and pressure (Abeele, Campbell, Eggermont, \& Roe, 2014), and thus may not always depend on adolescents' digital skills. Moreover, experiencing cyberbullying is often highly associated with experiencing offline cyberbullying (Beran \& Li, 2007; Kowalski, Morgan, \& Limber, 2012; Waasdorp \& Bradshaw, 2015), and may thus also not depend as much on digital skills.

At the same time, when experiencing online risks, there are certain skills that adolescents may need to cope with such risks. Future research may therefore find a fruitful task in investigating the type of coping mechanisms that adolescents adopt, both offline and online, and what role parents, schools and peers can play herein. Some researchers have started to focus on resilience, as the ability to deal with negative experiences and display coping strategies, such as blocking the sender of unwelcome messages (e.g. insults) (Vandoninck, D'Haenens, \& Roe, 2013). However, research has predominantly focused on coping strategies for cyberbullying (Lam \& Frydenberg, 2009; Machackova, Cerna, Sevcikova, Dedkova, \& Daneback, 2013; Machmutow, Perren, Sticca, \& Alsaker, 2012; Riebel, Jäger, \& Fischer, 2009) and has not considered any of the other risks, such as encountering online violence and pornography, or talking to strangers.

In any case, it has been found that the more digitally literate the 
children are, the more online coping strategies they use (Vandoninck et al., 2013). In this way, digital skills could have an indirect impact on dealing with online risks through developing coping skills. However, as other scholars have found that being more digitally competent does not reduce harm associated with online risks (Staksrud et al., 2013), more research is needed on resilience and coping to know if digital skills could reduce such harm indirectly through increasing resilience.

\subsection{Implications for research on parental mediation and adolescents' online skills and experiences}

Firstly, and as we expected, we found that restrictive parental mediation is negatively related to the level of digital skills. In brief, the more frequent adolescents perceive their parents to engage in restrictive mediation of their online media use, the less digitally skilled teenagers are. These results suggest that restrictive mediation is not the most appropriate type of mediation because, by restricting adolescents' use of digital media, we are limiting their development of digital skills too. Previous research has shown that restrictive mediation is related to a reduction of online risks and online opportunities (Daud et al., 2014; Lee, 2012; Lee \& Chae, 2012; Livingstone et al., 2017b), but it has not considered the role of digital literacy in that connection. Our study shows that restrictive mediation would be diminishing online risks through the reduction of digital skills.

Furthermore, the indirect impact of restrictive parental mediation through digital skills is more pronounced for online opportunities than online risks. This means that restrictive parental mediation would be reducing online risks mostly at the expense of online opportunities. As Sonck and de Haan (2014) argue, parents need to understand that risks exist and that these risks are part of the increasingly digital lifestyles of young people. Restricting the use of digital media for fear of risks is limiting and affecting the development of skills and opportunities of teenagers.

Contrary to previous research (Duerager \& Livingstone, 2012), active mediation has no significant indirect relationship with online risks and opportunities through digital skills. One explanation could be that parents are often also not digitally literate themselves (Dincer, 2012; Terras \& Ramsay, 2016). When parents engage in active mediation, this may perhaps attest to an overall supporting bond between parents and children which has been associated with overall avoidance of risk behaviour and positive development in adolescence (Buijzen \& Valkenburg, 2005; Chen \& Chng, 2016; Clark, 2011). However, active mediation may not have much to do with children actually learning from their parents how to engage with digital technology. Relatedly, digital technologies may call for new ways of parental mediation. In line with this notion, 'participatory learning' has been suggested as a new strategy of active mediation, and involves parents and children learning digital skills by jointly interacting with digital media. In this case, parents would be listeners and co-creators who invite their children to serve as leaders and guides into experiences with digital media (Clark, 2011).

As far as we know, this is the first attempt to analyse how adolescents' digital skills mediate the influence of parental mediation on online risks and online opportunities. Therefore, our study has important implications for this field, as the results show that parents are not actively contributing to their children's development of digital skills and a subsequent effective use of digital devices and online opportunities.

First, through restrictive mediation and the control of adolescents' activities and time online, parents are holding back the development of digital skills. It seems logical, as parents are not really teaching their children how to use digital devices or how to protect their digital identity. They are just checking their children messages or preventing them from visiting certain sites. However, it had seemed that active parental mediation could have a positive effect on adolescents' digital skills. Through this type of mediation, parents try to provide their children with guidance and advice in the use of digital media (e.g. explaining why some websites are good or bad, or suggesting ways to use digital devices safely). However, our results show that active mediation has no relationship with digital skills. As we said, it may be the case that parents are not digitally literate themselves and, therefore, not able to teach their children digital skills. Traditionally, a major part of responsibility for children's online safety has been attribute to parents (Sonck \& de Haan, 2014). Nonetheless, as we can conclude, parental mediation of digital media would not be as effective as we tend to think.

Future research should further investigate whether parents indeed currently lack the knowledge to teach their children digital skills, but if this is the case, we need to focus more on improving parents' digital skills and provide them tools for parenting in a digital age. Moreover, the fact that active mediation of parents is not related to adolescents' digital skills also suggests that adolescents adopt their digital literacy skills from other sources than their parents and independently build their digital skills, which subsequently form their online experiences. For instance, children's digital literacy skills have previously been associated with their engagement in leisure activities with digital media (Appel, 2012). Future research should investigate how adolescents adopt digital skills exactly, and which type of adolescents may be more or less able to do so. In that way, we can try to assist those adolescents that may not be able to independently become digitally literate.

\subsection{Strengths and limitations}

The present study suffers from several limitations that call for improvement in future research. First, the model fits of the factor analysis of the Digital Literacy Scale and of our model for hypotheses testing were just short of the recommended criteria. This means that the current data does not reflect the constructs and relationships in the population very well. This may be due to suboptimal measurements of the constructs in our study. In this regard, the communication skill factor in the Digital Literacy Scale shows low internal consistency (Cronbach's alpha $=0.46$ ). Moreover, the informational skill factor has a questionable reliability (Cronbach's alpha $=0.63$ ) and it shows the weakest relationship to the secondorder factor, digital literacy (standardized regression weight $=0.401$ ). This raises the issue of whether digital literacy and media literacy or news media literacy have a stronger relationship than digital literacy and informational literacy. Future research should address this issue in detail.

As we were in the early stages of the research, intending to stablish the validity and the structure of the Digital Literacy Scale, we decided to retain both factors, although admitting that their reliability is low. In the case of the communication skill, this factor is only measured through three items and it seems that new items could be added with the aim of improving internal consistency. Moreover, wording of the actual items should be checked again in order to look for enhancements. Therefore, future research may look into improvements of the measurements of the Digital Literacy Scale, and in particular for the factors communication skill and informational skill.

Second, the sample was taken only from Spanish secondary schools. As such, the generalizability of the findings to other countries, especially countries with lower levels of internet access, may be limited. However, it should be stressed that, at the same time, a strength of the present study is that adolescents were 
recruited through schools, which reduces the chance of selfselection bias of the adolescents. Moreover, the sample included adolescents from both rural and urban areas, which increases the generalizability of the results in terms of demographics of our sample.

A final and major limitation of the study is its cross-sectional character. As a result, it is not possible to determine causal relationships and demonstrate that restrictive mediation reduces digital skills. It could be that adolescents who are digital literate or who experience more online risks elicit more restrictive parental mediation out of concern for possible negative consequences. In fact, as has been argued previously (e.g., Appel, 2012), the relationship between digital media use and digital skills is likely reciprocal. Therefore, future research should investigate these relationships longitudinally.

Despite these limitations, to our knowledge this is the first study to examine how digital skills mediate the relationship between parental mediation and online risks and online opportunities, and thus provides new insights in how adolescents can make use of their digital environments in a beneficial way, and how parents can play a role herein. In addition, this study provides with several theoretical and empirical contributions to the study of adolescents' digital literacy. First, we have validated the Digital Literacy Scale. Despite some room for improvement in the measurement, we argue that even in its current state this is a valid and reliable instrument for measuring digital skills on teenagers and as such fills a gap in the field of digital literacy research. Second and finally, our study builds a theoretical model explaining the mediation role of adolescents' digital skills on the relationship between parental mediation and online risks and opportunities. Previous studies have only focused on the influence of parental mediation on online risks and opportunities, and very few studies have evaluated the impact of this mediation on adolescents' digital skills. Therefore, our research helps us understand how digital skills have a mediating role between (restrictive) parental behaviours and adolescents' online experiences that previous studies have not addressed.

\section{Acknowledgements}

Our sincere thanks to the students, teachers and principals in the schools for contributing data for analysis. We are also grateful to the reviewers for their careful revision and their suggestions in the revision process. This work was supported by the Government of Castile and Leon (Spain) and the European Social Fund [EDU/1083/ 2013].

\section{Appendix A}

Digital Literacy Scale: 6 factors and 28 items.

\section{Technological skill}

I know how to bookmark a website I like so I can view it later. I always know how to download/save a photo I found online. I know how to download information I found online.

I always know how to connect to a Wi-Fi network, no matter the device or where I am.

I know how to use shortcut keys (e.g. CTRL $+\mathrm{Co} c m d+\mathrm{C}$ for copy).

I do not like downloading apps for smartphones as I find difficult to learn how to use them (recoded).

If I want to install new programs on my computer, I will ask someone to do it for me because I do not know (recoded).

\section{Personal security skill}

I know how to deactivate the function showing my geographical position (e.g. Facebook, apps).

I know when I can post pictures and videos of other people online.

I know how to use 'report abuse' buttons on social media sites (e.g., someone uses my photo without my permission).

I know how to change the sharing settings of social media to choose what others can see about me (friends of friends, friends only, only me).

\section{Critical skill}

I know how to compare different sources to decide if information is true.

I know how to determine if the information I find online is reliable.

I know how to identify the author of the information and evaluate their reliability.

I know how to compare different apps in order to choose which one is most reliable and secure.

If I meet someone online, I know how to check if their profile is real.

\section{Devices security skill}

I use software to detect and remove viruses.

I know how to detect a virus in my digital device.

I know how to block unwanted or junk mail/spam.

If something doesn't work occurs while I am using a device (computer, smartphone, etc.), I usually know what it is and how to fix the problem.

\section{Informational skill}

I find hard to decide what the best keywords are for online searching (recoded).

I find confusing the way in which many websites are designed (recoded).

Sometimes I find difficult to determine how useful the information is for my purpose (recoded).

I get tired when looking for information online.

Sometimes I end up on websites without knowing how I got there.

\section{Communication skill}

Depending on who I want to communicate with, it is better to use one method over the other (make a call, send a WhatsApp message, send an email, etc.)

I know how to send any file to a contact using a smartphone.

No matter with who I communicate: emojis are always useful (recoded).

\section{References}

Abeele, M. V., Campbell, S. W., Eggermont, S., \& Roe, K. (2014). Sexting, mobile porn use, and peer group Dynamics : Boys' and girls' self-perceived popularity, need for popularity, and perceived peer pressure. Media Psychology, 17, 6-33. https:/| doi.org/10.1080/15213269.2013.801725.

Adachi, P. J. C., \& Willoughby, T. (2013). More than just fun and Games: The longitudinal relationships between strategic video games, self-reported problem solving skills, and academic grades. Journal of Youth and Adolescence, 42(7), 1041-1052. https://doi.org/10.1007/s10964-013-9913-9.

Álvarez-García, D., Dobarro, A., \& Núñez, J. C. (2015). Validez y fiabilidad del Cuestionario de cibervictimización en estudiantes de Secundaria. Aula Abierta 
43(1), 32-38. https://doi.org/10.1016/j.aula.2014.11.001

Álvarez, M., Torres, A., Rodríguez, E., Padilla, S., \& Rodrigo, M. J. (2013). Attitudes and parenting dimensions in parents' regulation of Internet use by primary and secondary school children. Computers \& Education, 67, 69-78. https://doi.org/ 10.1016/j.compedu.2013.03.005.

Appel, M. (2012). Are heavy users of computer games and social media more computer literate? Computers \& Education, 59(4), 1339-1349. https://doi.org/ 10.1016/j.compedu.2012.06.004.

Area-Moreira, M., \& Ribeiro-Pessoa, M. T. (2012). From solid to Liquid: New literacies to the cultural changes of web 2.0. Comunicar, 19(38), 13-20. https:// doi.org/10.3916/C38-2011-02-01.

Austin, E. W., Pinkleton, B. E., \& Fujioka, Y. (2000). The role of interpretation processes and parental discussion in the Media's effects on adolescents' use of alcohol. Pediatrics, 105(2), 343-349. https://doi.org/10.1542/peds.105.2.343.

Barbeite, F. G., \& Weiss, E. M. (2004). Computer self-efficacy and anxiety scales for an Internet sample: Testing measurement equivalence of existing measures and development of new scales. Computers in Human Behavior, 20(1),1-15. https:/| doi.org/10.1016/S0747-5632(03)00049-9.

Bawden, D. (2001). Information and digital literacies: A review of concepts. Journal of Documentation, 57(2), 218-259. https://doi.org/10.1108/ EUM0000000007083.

Bawden, D. (2002). Revisión de los conceptos de alfabetización informacional y alfabetización digital. Anales de Documentación, 5(1997), 361-408. https:// doi.org/10.6018/2261.

Baxter, L. A., Bylund, C. L., Imes, R., \& Routsong, T. (2009). Parent-child perceptions of parental behavioral control through rule-setting for risky health choices during adolescence. Journal of Family Communication, 9(4), 251-271. https:// doi.org/10.1080/15267430903255920.

Bender, P. K., Plante, C., \& Gentile, D. A. (2018). The effects of violent media content on aggression. Current Opinion in Psychology, 19, 104-108. https://doi.org/ 10.1016/j.copsyc.2017.04.003.

Beran, T., \& Li, Q. (2007). The relationship between cyberbullying and school bullying. Journal of Student Wellbeing, 1(2), 16-33.

Bersamin, M., Todd, M., Fisher, D. A., Hill, D. L., Grube, J. W., \& Walker, S. (2008). Parenting practices and adolescent sexual behavior: A longitudinal study. Journal of Marriage and Family, 70(1), 97-112. https://doi.org/10.1111/j.17413737.2007.00464

Beyens, I., Vandenbosch, L., \& Eggermont, S. (2015). Early adolescent boys' exposure to internet Pornography: Relationships to pubertal timing, sensation seeking, and academic performance. The Journal of Early Adolescence, 35(8), 1045-1068. https://doi.org/10.1177/0272431614548069.

Boyaci, Ş., \& Atalay, N. (2016). A scale development for 21st century skills of primary school students: A validity and reliability study. International Journal of Instruction, 9(1), 1694609. https://doi.org/10.12973/iji.2016.9111a.

Brown, T. A. (2015). Confirmatory factor analysis for applied research (2nd ed.). London: The Guilford Press.

Browne, M. W., \& Cudeck, R. (1992). Alternative ways of assessing model fit. Sociological Methods \& Research, 21(2), 230-258. https://doi.org/10.1177/ 0049124192021002005 .

Buijzen, M., Rozendaal, E., Moorman, M., \& Tanis, M. (2008). Parent versus child reports of parental advertising mediation: Exploring the meaning of agreement. Journal of Broadcasting \& Electronic Media, 52(4), 509-525. https://doi.org/ $10.1080 / 08838150802437180$.

Buijzen, M., \& Valkenburg, P. M. (2005). Parental mediation of undesired advertising effects. Journal of Broadcasting \& Electronic Media, 49(2), 153-165. https:// doi.org/10.1207/s15506878jobem4902.

Bunz, U. (2004). The Computer-Email-Web (CEW) fluency scale-development and validation. International Journal of Human-computer Interaction, 17(May 2001), 479-506. https://doi.org/10.1207/s15327590ijhc1704_3.

Bunz, U., Curry, C., \& Voon, W. (2007). Perceived versus actual computer-email-web fluency. Computers in Human Behavior, 23(5), 2321-2344. https://doi.org/ 10.1016/j.chb.2006.03.008.

Cabero, J., Marín, V., \& Llorente, M. D. C. (2012). Desarrollar la competencia digital. Educación mediática a lo largo de toda la vida (Sevilla: MAD).

Calvani, A., Fini, A., Ranieri, M., \& Picci, P. (2012). Are young generations in secondary school digitally competent? A study on Italian teenagers. Computers \& Education, 58(2), 797-807. https://doi.org/10.1016/j.compedu.2011.10.004.

Chen, V. H. H., \& Chng, G. S. (2016). Active and restrictive parental mediation over time: Effects on youths' self-regulatory competencies and impulsivity. Computers \& Education, 98, 206-212. https://doi.org/10.1016/ j.compedu.2016.03.012.

Chen, F. F., Sousa, K. H., \& West, S. G. (2005). Teacher's Corner: Testing measurement invariance of second-order factor models. Structural Equation Modeling: A Multidisciplinary Journal, 12(3), 471-492. https://doi.org/10.1207/ s15328007sem1203_7.

Chisholm, J. F. (2006). Cyberspace violence against girls and adolescent females. Annals of the New York Academy of Sciences, 74-89. https://doi.org/10.1196/ annals.1385.022, 1087.

Clark, L. S. (2011). Parental mediation theory for the digital age. Communication Theory, 21(4), 323-343. https://doi.org/10.1111/j.1468-2885.2011.01391.x.

Claro, M., Preiss, D. D., San Martín, E., Jara, I., Hinostroza, J. E., Valenzuela, S., \& Nussbaum, M. (2012). Assessment of 21st century ICT skills in Chile: Test design and results from high school level students. Computers \& Education, 59(3), 1042-1053. https://doi.org/10.1016/j.compedu.2012.04.004.

Daud, A., Omar, S. Z., Hassan, M. S., Bolong, J., \& Teimouri, M. (2014). Parental mediation of children's positive use of the internet. Life Science Journal, 11(8) 360-369.

De Wit, K., Heerwegh, D., \& Verhoeven, J. C. (2014). Can openness to ICT and scientific research predict the ICT skills and ICT use of bachelor's students? Computers \& Education, 78, 397-413. https://doi.org/10.1016/ j.compedu.2014.07.003.

Dehue, F., Bolman, C., \& Völlink, T. (2008). Cyberbullying: Youngsters' experiences and parental perception. CyberPsychology and Behavior, 11(2), 217-223. https:// doi.org/10.1089/cpb.2007.0008.

van Deursen, A. J. A. M., \& van Diepen, S. (2013). Information and strategic internet skills of secondary students: A performance test. Computers \& Education, 63 218-226. https://doi.org/10.1016/j.compedu.2012.12.007.

van Deursen, A. J. A. M., van Dijk, J. A. G. M., \& Peters, O. (2012). Proposing a survey instrument for measuring operational, formal, information, and strategic internet skills. International Journal of Human-computer Interaction, 28(12) 827-837. https://doi.org/10.1080/10447318.2012.670086.

Dincer, S. (2012). A study of the relationship between pupils and parents' computer literacy level and use. Procedia Social and Behavioral Sciences [4th World Conference on Educational Sciences], 46(2007), 484-489. https://doi.org/10.1016/ j.sbspro.2012.05.146.

Doornwaard, S. M., van den Eijnden, R., Baams, L., Vanwesenbeeck, I., \& ter Bogt, T. (2016). Lower psychological well-being and excessive sexual interest predict symptoms of compulsive use of sexually explicit internet material among adolescent boys. Journal of Youth and Adolescence, 45(1), 73-84. https://doi.org/ 10.1007/s10964-015-0326-9.

Doornwaard, S. M., van den Eijnden, R., Overbeek, G., \& ter Bogt, T. (2015). Differential Developmental Profiles of Adolescents Using Sexually Explicit Internet Material. The Journal of Sex Research, 52(3), 269-281. https://doi.org/10.1080/ 00224499.2013.866195.

Dornbusch, S. M., Ritter, P. L., Leiderman, P. H., Roberts, D. F., \& Fraleigh, M. J. (1987) The relation of parenting style to adolescent school performance. Child Development, 58(5), 1244-1257. https://doi.org/10.2307/1130618.

Duerager, A., \& Livingstone, S. (2012). How can parents support children's internet safety? London: LSE. EU Kids Online. Retrieved from http://eprints.lse.ac.uk/ 42872/.

Duran, R. L., Yousman, B., Walsh, K. M., \& Longshore, M. A. (2008). Holistic media Education: An assessment of the effectiveness of a college course in media literacy. Communication Quarterly, 56(1), 49-68. https://doi.org/10.1080 01463370701839198.

Durndell, A., \& Haag, Z. (2002). Computer self efficacy, computer anxiety, attitudes towards the Internet and reported experience with the Internet, by gender, in an East European sample. Computers in Human Behavior, 18(5), 521-535. https://doi.org/10.1016/S0747-5632(02)00006-7.

Eshet-Alkalai, Y. (2004). Digital literacy: A conceptual framework for survival skills in the digital era. Journal of Educational Multimedia and Hypermedia, 13(1), 93-106. Retrieved from http://www.editlib.org/p/4793.

Eshet-alkalai, Y., \& Chajut, E. (2009). Changes over time in digital literacy. CyberPsychology and Behavior, 12(6). https://doi.org/10.1089/cpb.2008.0264.

Eurostat. (2016). Internet access and use statistics - households and individuals Bruselas: Eurostat.

Field, A. P. (2013). Discovering statistics using IBM SPSS statistics (4th ed.). London: Sage Publications.

Fraillon, J., Ainley, J., Schulz, W., Friedman, T., \& Gebhardt, E. (2014). Preparing for life in a digital Age: The IEA international computer and information literacy study international report. Australia: Springer International Publishing. Retrieved from http://research.acer.edu.au/cgi/viewcontent.cgi?article=1009\&context=ict_ literacy.

Fujioka, Y., \& Weintraub Austin, E. (2003). The implications of vantage point in parental mediation of television and Child's attitudes toward drinking alcohol. Journal of Broadcasting \& Electronic Media, 47(3), 418-434. https://doi.org/ 10.1207/s15506878jobem4703 6.

Gastelú, C. A. T., Kiss, G., \& Domínguez, A. L. (2015). Level of ICT competencies at the university. Procedia - Social and Behavioral Sciences, 174, 137-142. https:// doi.org/10.1016/j.sbspro.2015.01.638.

Gati, A., Tényi, T., Túry, F., \& Wildmann, M. (2002). Anorexia nervosa following sexual harassment on the internet: A case report. International Journal of Eating Disorders, 31(4), 474-477. https://doi.org/10.1002/eat.10029.

Gebhardt, E., Fraillon, J., Schulz, W., O'Malley, K., Freeman, C., Murphy, M., et al (2012). National assessment program - ICT literacy technical report (Vol. 2011, pp. 1-92). Retrieved from http://www.nap.edu.au/verve/_resources/NAP_ICTL_ 2011_Technical_Report_Final.pdf.

Gui, M., \& Argentin, G. (2011). Digital skills of internet natives: Different forms of digital literacy in a random sample of northern Italian high school students. New Media \& Society, 13(6). https://doi.org/10.1177/1461444810389751, 1461444810389751.

Gutiérrez, A. (2003). Alfabetización digital: Algo más que ratones y teclas (Barcelona: Gedisa).

Halliwell, E., Easun, A., \& Harcourt, D. (2011). Body dissatisfaction: Can a short media literacy message reduce negative media exposure effects amongst adolescent girls? British Journal of Health Psychology, 16(2), 396-403. https:/ doi.org/10.1348/135910710X515714.

Hargittai, E. (2008). An update on survey measures of web-oriented digital literacy. Social Science Computer Review, 27(1), 130-137. https://doi.org/10.1177| 0894439308318213.

Hargittai, E., \& Hsieh, Y. P. (2012). Succinct survey measures of web-use skills. Socia 
Science Computer Review, 30(1), 95-107. https://doi.org/10.1177/ 0894439310397146.

Hayes, A. F. (2005). Statistical methods for communication science. Mahwah, New Jersey: Lawrence Erlbaum Associates.

Heinssen, R. K., Glass, C. R., \& Knight, L.a. (1987). Assessing computer anxiety: Development and validation of the computer anxiety rating scale. Computers in Human Behavior, 3(1), 49-59. https://doi.org/10.1016/0747-5632(87)90010-0.

Helsper, E. J., \& Eynon, R. (2013). Distinct skill pathways to digital engagement. European Journal of Communication, 28(6), 696-713. https://doi.org/10.1177/ 0267323113499113.

Hermida, R. (2015). The problem of allowing correlated errors in structural equation Modeling: Concerns and considerations. Computational Methods in Social Sciences, 3(1), 5-17. Retrieved from http://cmss.univnt.ro/wp-content/uploads/ vol/split/vol_III_issue_1/CMSS_vol_III_issue_1_art.001.pdf.

Hooper, D., Coughlan, J., \& Mullen, M. (2008). Structural equation modelling: guidelines for determining model fit structural equation modelling : Guidelines for determining model fit. Electronic Journal of Business Research Methods, 6(1), 53-60. https://doi.org/10.1037/1082[HYPHEN]989X.12.1.58.

Ihmeideh, F. M., \& Shawareb, A. A. (2014). The association between internet parenting styles and Children's use of the internet at home. Journal of Research in Childhood Education, 28(4), 411-425. https://doi.org/10.1080/ 02568543.2014.944723.

Irving, L. M., Dupen, J., \& Berel, S. (1998). A media literacy program for high school females. Eating Disorders, 6(2), 119-131. https://doi.org/10.1080/ 10640269808251248.

Jackson, L. A., von Eye, A., Biocca, F. A., Barbatsis, G., Zhao, Y., \& Fitzgerald, H. E. (2006). Does home internet use influence the academic performance of lowincome children? Developmental Psychology, 42(3), 429-435. https://doi.org/ 10.1037/0012-1649.42.3.000.

Jeong, S.-H., Cho, H., \& Hwang, Y. (2012). Media literacy interventions: A metaanalytic review. Journal of Communication, 62(3), 454-472. https://doi.org 10.1111/j.1460-2466.2012.01643.x.

Khurana, A., Bleakley, A., Jordan, A. B., \& Romer, D. (2015). The protective effects of parental monitoring and internet restriction on adolescents' risk of online harassment. Journal of Youth and Adolescence, 44(5), 1039-1047. https://doi.org/ 10.1007/s10964-014-0242-4.

Kirwil, L. (2009). Parental mediation of Children's internet use in different european countries. Journal of Children and Media, 3(4), 394-409. https://doi.org/10.1080 17482790903233440 .

Kline, R. (2013). Exploratory and confirmatory factor analysis. In Y. Petscher, \& C. Schatsschneider (Eds.), Applied quantitative analysis in the social sciences (pp. 171-207). New York: Routledge.

Koc, M., \& Barut, E. (2016). Development and validation of New Media Literacy Scale (NMLS) for university students. Computers in Human Behavior, 63, 834-843. https://doi.org/10.1016/j.chb.2016.06.035.

Koltay, T. (2011). The media and the literacies: Media literacy, information literacy, digital literacy. Media, Culture \& Society, 33(2), 211-221. https://doi.org/10.1177 0163443710393382.

Koutamanis, M., Vossen, H. G. M., Peter, J., \& Valkenburg, P. M. (2013). Practice makes perfect: The longitudinal effect of adolescents' instant messaging on their ability to initiate offline friendships. Computers in Human Behavior, 29(6), 2265-2272. https://doi.org/10.1016/j.chb.2013.04.033.

Kowalski, R. M., Morgan, C. A., \& Limber, S. P. (2012). Traditional bullying as a potential warning sign of cyberbullying. School Psychology International, 33(5) 505-519. https://doi.org/10.1177/0143034312445244.

Ktoridou, D., Eteokleous, N., \& Zahariadou, A. (2012). Exploring parents' and children's awareness on internet threats in relation to internet safety. Campus-wide Information Systems, 29(3), 133-143. https://doi.org/10.1108 10650741211243157.

Kuhlemeier, H., \& Hemker, B. (2007). The impact of computer use at home on students' Internet skills. Computers \& Education, 49(2), 460-480. https:// doi.org/10.1016/j.compedu.2005.10.004.

Lam, C. W. C., \& Frydenberg, E. (2009). Coping in the Cyberworld: Program implementation and evaluation - a pilot project. Australian Journal of Guidance and Counselling, 19(2), 196-215. https://doi.org/10.1375/ajgc.19.2.196.

Lau, W. W. F., \& Yuen, A. H. K. (2013). Adolescents' risky online behaviours: The influence of gender, religion, and parenting style. Computers in Human Behavior, 29(6), 2690-2696. https://doi.org/10.1016/j.chb.2013.07.005.

Lee, S.-J. (2012). Parental restrictive mediation of children's internet use: Effective for what and for whom? New Media \& Society, 15(4), 466-481. https://doi.org/ $10.1177 / 1461444812452412$.

Lee, S.-J., \& Chae, Y.-G. (2012). Balancing participation and risks in Children's internet Use: The role of internet literacy and parental mediation. Cyberpsychology, Behavior, and Social Networking, 15(5), 257-262. https://doi.org/ 10.1089/cyber.2011.0552.

Len-Ríos, M. E., Hughes, H. E., McKee, L. G., \& Young, H. N. (2016). Early adolescents as publics: A national survey of teens with social media accounts, their media use preferences, parental mediation, and perceived internet literacy. Public Relations Review, 42(1), 101-108. https://doi.org/10.1016/j.pubrev.2015.10.003.

Leung, L., \& Lee, P. S. N. (2012a). Impact of internet literacy, internet addiction symptoms, and internet activities on academic performance. Social Science Computer Review, 30(4), 403-418. https://doi.org/10.1177/0894439311435217.

Leung, L., \& Lee, P. S. N. (2012b). The influences of information literacy, internet addiction and parenting styles on internet risks. New Media \& Society, 14(1), 117-136. https://doi.org/10.1177/1461444811410406.
Liau, A. K., Khoo, A., \& Hwaang, P. (2005). Factors influencing adolescents engagement in risky internet behavior. CyberPsychology and Behavior, 8(6), 513-520. https://doi.org/10.1089/cpb.2005.8.513.

Li, Y., \& Ranieri, M. (2010). Are "digital natives" really digitally competent?-A study on Chinese teenagers. British Journal of Educational Technology, 41(6), 1029-1042. https://doi.org/10.1111/j.1467-8535.2009.01053.x.

Livingstone, S. (2004). What is media literacy? InterMedia, 32(3), 18-20.

Livingstone, S. (2013). Online risk, harm and vulnerability: Reflections on the evidence base for child Internet safety policy. Zer: Revista de Estudios de Comunicacion, 18(35), 13-28. Retrieved from http://www.ehu.eus/zer/hemeroteca/ pdfs/zer35-01-livingstone.pdf.

Livingstone, S., Haddon, L., Görzig, A., \& Ólafsson, K. (2011). Risks and safety on the internet: The perspective of European children. Full findings. London: LSE. EU Kids Online. Retrieved from http://eprints.lse.ac.uk/33731/.

Livingstone, S., \& Helsper, E. J. (2010). Balancing opportunities and risks in teenagers' use of the internet: The role of online skills and internet self-efficacy. New Media \& Society, 12(2), 309-329. https://doi.org/10.1177/1461444809342697.

Livingstone, S., Mascheroni, G., Dreier, M., Chaudron, S., \& Lagae, K. (2015). How parents of young children manage digital devices at home: The role of income, education and parental style. London: LSE (EU Kids Online).

Livingstone, S., Mascheroni, G., \& Staksrud, E. (2017a). European research on children's internet use: Assessing the past and anticipating the future. New Media \& Society, 1-20. https://doi.org/10.1177/1461444816685930.

Livingstone, S., Ólafsson, K., Helsper, E. J., Lupiáñez-Villanueva, F., Veltri, G. A., \& Folkvord, F. (2017b). Maximizing opportunities and minimizing risks for children Online: The role of digital skills in emerging strategies of parental mediation. Journal of Communication, 67, 82-105. https://doi.org/10.1111/jcom.12277.

Lwin, M. O., Stanaland, A. J. S., \& Miyazaki, A. D. (2008). Protecting children's privacy online: How parental mediation strategies affect website safeguard effectiveness. Journal of Retailing, 84(2), 205-217. https://doi.org/10.1016/ j.jretai.2008.04.004.

Machackova, H., Cerna, A., Sevcikova, A., Dedkova, L., \& Daneback, K. (2013). Effectiveness of coping strategies for victims of cyberbullying. Cyberpsychology: Journal of Psychosocial Research on Cyberspace, 7(3). https://doi.org/10.5817/ CP2013-3-5.

Machmutow, K., Perren, S., Sticca, F., \& Alsaker, F. D. (2012). Peer victimisation and depressive symptoms: Can specific coping strategies buffer the negative impact of cybervictimisation? Emotional \& Behavioural Difficulties, 17(3-4), 403-420. https://doi.org/10.1080/13632752.2012.704310.

Mahmoudi, H., Koushafar, M., Saribagloo, J. A., \& Pashavi, G. (2015). The effect of computer games on speed, attention and consistency of learning mathematics among students. Procedia - Social and Behavioral Sciences, 176(March), 419-424. https://doi.org/10.1016/j.sbspro.2015.01.491.

Maksl, A., Ashley, S., \& Craft, S. (2015). Measuring news media literacy. Journal of Media Literacy Education, 6(3), 29-45. Retrieved from http://digitalcommons. uri.edu/jmle/vol6/iss3/3/.

Maksl, A., Craft, S., Ashley, S., \& Miller, D. (2017). The usefulness of a news media literacy measure in evaluating a news literacy curriculum. Journalism and Mass Communication Educator, 72(2), 228-241. https://doi.org/10.1177/ 1077695816651970.

Margaryan, A., Littlejohn, A., \& Vojt, G. (2011). Are digital natives a myth or reality? University students' use of digital technologies. Computers \& Education, 56(2), 429-440. https://doi.org/10.1016/j.compedu.2010.09.004.

Martin, A. (2005). DigEuLit european framework for digital literacy: A progress report. Journal of eLiteracy, 2, 130-266. Retrieved from http://www.jelit.org/65/ 01/JeLit_Paper_31.pdf?utm_source=twitterfeed\&utm_medium=twitter.

Martínez, J. I., Cortés, A., Medrano, C., \& Apodaca, P. (2014). Internet use and parental mediation: A cross-cultural study. Computers \& Education, 70, 212-221. https://doi.org/10.1016/j.compedu.2013.07.036.

Miller, B. C. (2002). Family influences on adolescent sexual and contraceptive behavior. The Journal of Sex Research, 39(1), 22-26. https://doi.org/10.1080/ 00224490209552115.

Mitchell, K. J., Finkelhor, D., \& Wolak, J. (2003). The exposure of youth to unwanted sexual material on the internet: A national survey of risk, impact, and prevention. Youth \& Society, 34(3), 330-358. https://doi.org/10.1177/ 0044118 X02250123.

Nathanson, A. I. (2001). Parent and child perspectives on the presence and meaning of parental television mediation. Journal of Broadcasting \& Electronic Media, 45(2), 201-220. https://doi.org/10.1207/s15506878jobem4502_1.

$\mathrm{Ng}, \mathrm{W}$. (2012). Can we teach digital natives digital literacy? Computers \& Education, 59(3), 1065-1078. https://doi.org/10.1016/j.compedu.2012.04.016.

Nikken, P., \& Schols, M. (2015). How and why parents guide the media use of young children. Journal of Child and Family Studies, 24(11), 3423-3435. https://doi.org/ 10.1007/s10826-015-0144-4.

Nixon, C. (2014). Current perspectives: The impact of cyberbullying on adolescent health. Adolescent Health, Medicine and Therapeutics, 5, 143-158. https://doi.org/ 10.2147/AHMT.S36456.

Noar, S. M. (2003). The role of structural equation modeling in scale development. Structural Equation Modeling: A Multidisciplinary Journal, 10(4), 622-647. https://doi.org/10.1207/S15328007SEM1004_8.

Ólafsson, K., Livingstone, S., \& Haddon, L. (2013). Children's use of online technologies in Europe. A review of the European evidence base. London: LSE (EU Kids Online).

Park, S., \& Burford, S. (2013). A longitudinal study on the uses of mobile tablet devices and changes in digital media literacy of young adults. Educational Media International, 50(4), 266-280. https://doi.org/10.1080/09523987.2013.862365. 
Patchin, J. W., \& Hinduja, S. (2010). Changes in adolescent online social networking behaviors from 2006 to 2009. Computers in Human Behavior, 26, 1818-1821. https://doi.org/10.1016/j.chb.2010.07.009.

Peter, J., \& Valkenburg, P. M. (2006). Adolescents' exposure to sexually explicit online material and recreational attitudes toward sex. Journal of Communication, 56(4), 639-660. https://doi.org/10.1111/j.1460-2466.2006.00313.x.

Peter, J., \& Valkenburg, P. M. (2007). Adolescents' exposure to a sexualized media environment and their notions of women as sex objects. Sex Roles, 56(5-6), 381-395. https://doi.org/10.1007/s11199-006-9176-y.

Peter, J., \& Valkenburg, P. M. (2008). Adolescents' exposure to sexually explicit internet material and sexual preoccupancy: A three-wave panel study. Media Psychology, 11(2), 207-234. https://doi.org/10.1080/15213260801994238.

Peter, J., \& Valkenburg, P. M. (2009). Adolescents' exposure to sexually explicit internet material and sexual satisfaction: A longitudinal study. Human Communication Research, 35(2), 171-194. https://doi.org/10.1111/j.14682958.2009.01343.x.

Peter, J., \& Valkenburg, P. M. (2014). Does exposure to sexually explicit Internet material increase body dissatisfaction? A longitudinal study. Computers in $\mathrm{Hu}$ man Behavior, 36, 297-307. https://doi.org/10.1016/j.chb.2014.03.071.

Pino Juste, M. R., \& Soto Carballo, J. (2010). Identificación del dominio de competencias digitales en el alumnado del grado de magisterio. Teoría de La Educación: Educación Y Cultura En La Sociedad de La Información, 11(3), 336-362. Retrieved from http://campus.usal.es/ revistas_trabajo/index.php/revistatesi/ article/view/7466.

Rasmussen, E. E., Ortiz, R. R., \& White, S. R. (2015). Emerging adults' responses to active mediation of pornography during adolescence. Journal of Children and Media, 9(2), 160-176. https://doi.org/10.1080/17482798.2014.997769.

Riebel, J., Jäger, R. S., \& Fischer, U. C. (2009). Cyberbullying in Germany - an exploration of prevalence, overlapping with real life bullying and coping strategies. Psychology Science Quarterly, 21(3), 298-314. Retrieved from http:/ www.psychologie-aktuell.com/fileadmin/download/PschologyScience/3-2009/ 05_riebel.pdf.

Riel, J., Christian, S., \& Hinson, B. (2012). Charting digital literacy: A framework for information technology and digital skills education in the community college (541).

Rodríguez-de-Dios, I., \& Igartua, J.-J. (2016). Skills of digital literacy to address the risks of interactive communication. Journal of Information Technology Research, 9(1), 54-64. https://doi.org/10.4018/JITR.2016010104.

Rodríguez-de-Dios, I., Igartua, J.-J., \& González-Vázquez, A. (2016). Development and validation of a digital literacy scale for teenagers. In Proceedings of the fourth international conference on technological ecosystems for enhancing multiculturality - TEEM '16 (pp. 1067-1072). New York, New York, USA: ACM Press. https://doi.org/10.1145/3012430.3012648.

Røkenes, F. M., \& Krumsvik, R. J. (2016). Prepared to teach ESL with ICT? A study of digital competence in Norwegian teacher education. Computers \& Education, 97, 1-20. https://doi.org/10.1016/j.compedu.2016.02.014.

Sasson, H., \& Mesch, G. (2014). Parental mediation, peer norms and risky online behavior among adolescents. Computers in Human Behavior, 33, 32-38. https:// doi.org/10.1016/j.chb.2013.12.025.

Schneider, S. K., O'Donnell, L., Stueve, A., \& Coulter, R. W. S. (2012). Cyberbullying, school bullying, and psychological distress: A regional census of high school students. American Journal of Public Health, 102(1), 171-177. https://doi.org/ 10.2105/AJPH.2011.300308.

Shapiro, J. J., \& Hughes, S. K. (1996). Information literacy as a liberal art: Enlightenment proposals for a new curriculum. Educom Review, 31(2), 159-162. Retrieved from http://net.educause.edu/apps/er/review/reviewArticles/.

Shin, W., Huh, J., \& Faber, R. J. (2012). Tweens' online privacy risks and the role of parental mediation. Journal of Broadcasting \& Electronic Media, 56(4), 632-649. https://doi.org/10.1080/08838151.2012.732135.

Shin, W., \& Ismail, N. (2014). Exploring the role of parents and peers in young adolescents' risk taking on social networking sites. Cyberpsychology, Behavior, and Social Networking, 17(9), 578-583. https://doi.org/10.1089/cyber.2014.0095.

Shin, W., \& Kang, H. (2016). Adolescents' privacy concerns and information disclosure online: The role of parents and the Internet. Computers in Human Behavior, 54, 114-123. https://doi.org/10.1016/j.chb.2015.07.062.

Slater, M. D. (2003). Alienation, aggression, and sensation seeking as predictors of adolescent use of violent film, computer, and website content. Journal of Communication, 53(1), 105-121.

Sonck, N., \& de Haan, J. (2013). How the internet skills of european 11- to 16-yearolds mediate between online risk and harm. Journal of Children and Media, 7(1) 79-95. https://doi.org/10.1080/17482798.2012.739783.

Sonck, N., \& de Haan, J. (2014). Safety by Literacy? Rethinking the role of digital skills in improving online safety. In Minding minors wandering the Web: Regulating online child safety (pp. 89-104). https://doi.org/10.1007/978-94-6265005-3_5.

Sonck, N., Livingstone, S., Kuiper, E., \& de Haan, J. (2011). Digital literacy and safety skills. London: London School of Economics \& Political Science (EU Kids Online).

Staksrud, E., Ólafsson, K., \& Livingstone, S. (2013). Does the use of social networking sites increase children's risk of harm? Computers in Human Behavior, 29(1), 40-50. https://doi.org/10.1016/j.chb.2012.05.026.

Steinberg, L., \& Morris, A. S. (2001). Adolescent development. Annual Review of Psychology, 52, 83-110. https://doi.org/10.1146/annurev.psych.52.1.83.

Süss, D. (2001). Computers and the internet in School: Closing the knowledge gap? In S. Livingstone, \& M. Bovill (Eds.), Children and their changing media environment (pp. 221-244). Mahway, NJ: Laerence Erlbaum Associates.

Symons, K., Ponnet, K., Emmery, K., Walrave, M., \& Heirman, W. (2017). Parental knowledge of adolescents' online content and contact risks. Journal of Youth and Adolescence, 46, 401-416. https://doi.org/10.1007/s10964-016-0599-7.

Teimouri, M., Hassan, M. S., Bolong, J., Daud, A., Yussuf, S., \& Adzharuddin, N. A. (2014). What is upsetting our children online? Procedia - Social and Behavioral Sciences, 155(October), 411-416. https://doi.org/10.1016/j.sbspro.2014.10.314.

Terras, M. M., \& Ramsay, J. (2016). Family digital literacy practices and Children's mobile phone use. Frontiers in Psychology, 7, 1-11. https://doi.org/10.3389/ fpsyg.2016.01957.

Thompson, S. (2003). Information literacy meeting of experts, Prague, the Czech Republic, September 20-23, 2003. Conference report. Retrieved from http://www. unesco.org/fileadmin/MULTIMEDIA/HQ/CI/CI/pdf/themes/info_lit_meeting prague_2003.pdf.

Tsai, M.-J., \& Tsai, C. C. (2010). Junior high school students' internet usage and selfefficacy: A re-examination of the gender gap. Computers \& Education, 54(4) 1182-1192. https://doi.org/10.1016/j.compedu.2009.11.004.

Valcke, M., Bonte, S., De Wever, B., \& Rots, I. (2010). Internet parenting styles and the impact on Internet use of primary school children. Computers \& Education 55(2), 454-464. https://doi.org/10.1016/j.compedu.2010.02.009.

Valcke, M., De Wever, B., Van Keer, H., \& Schellens, T. (2011). Long-term study of safe Internet use of young children. Computers \& Education, 57(1), 1292-1305. https://doi.org/10.1016/j.compedu.2011.01.010.

Valkenburg, P. M., \& Peter, J. (2009). Social consequences of the internet for adolescents a decade of research. Current Directions in Psychological Science, 18(1), 1-5. https://doi.org/10.1111/j.1467-8721.2009.01595.x.

Valkenburg, P. M., Piotrowski, J. T., Hermanns, J., \& de Leeuw, R. (2013). Developing and validating the perceived parental media mediation scale: A selfdetermination perspective. Human Communication Research, 39(4), 445-469. https://doi.org/10.1111/hcre.12010.

Vandoninck, S., D'Haenens, L., \& Donoso, V. (2010). Digital literacy of flemish youth: How do they handle online content risks? Communications, 35(4), 397-416. https://doi.org/10.1515/COMM.2010.021.

Vandoninck, S., D'Haenens, L., \& Roe, K. (2013). Online risks. Journal of Children and Media, 7(1), 60-78. https://doi.org/10.1080/17482798.2012.739780.

Vaterlaus, J. M., Beckert, T. E., Tulane, S., \& Bird, C. V. (2014). "They always ask what I'm doing and who I'm talking to": Parental mediation of adolescent interactive technology use. Marriage \& Family Review, 50(8), 691-713. https://doi.org/ 10.1080/01494929.2014.938795.

Vossen, H. G. M., \& Valkenburg, P. M. (2016). Do social media foster or curtail adolescents' empathy? A longitudinal study. Computers in Human Behavior, 63 118-124. https://doi.org/10.1016/j.chb.2016.05.040.

Vraga, E., Tully, M., Kotcher, J. E., Smithson, A., \& Broeckelman-post, M. (2015). A multi-dimensional approach to measuring news media literacy. Journal of Media Law \& Ethics, 7(3), 41-53. Retrieved from http://digitalcommons.uri.edu/ jmle/vol7/iss $3 / 4 /$.

Waasdorp, T. E., \& Bradshaw, C. P. (2015). The overlap between cyberbullying and traditional bullying. Journal of Adolescent Health, 56(5), 483-488. https:/ doi.org/10.1016/j.jadohealth.2014.12.002.

Wilkinson, A., Roberts, J., \& While, A. E. (2010). Construction of an instrument to measure student information and communication technology skills, experience and attitudes to e-learning. Computers in Human Behavior, 26(6), 1369-1376. https://doi.org/10.1016/j.chb.2010.04.010.

Wilson, M., Scalise, K., \& Gochyyev, P. (2015). Rethinking ICT literacy: From computer skills to social network settings. Thinking Skills and Creativity, 18, 65-80. https://doi.org/10.1016/j.tsc.2015.05.001.

Ybarra, M. L., Diener-West, M., Markow, D., Leaf, P. J., Hamburger, M., \& Boxer, P. (2008). Linkages between internet and other media violence with seriously violent behavior by youth. Pediatrics, 122(5), 929-937. https://doi.org/10.1542/ peds.2007-3377.

Ybarra, M. L., Mitchell, K. J., Wolak, J., \& Finkelhor, D. (2006). Examining characteristics and associated distress related to internet Harassment: Findings from the second youth internet safety survey. Pediatrics, 118(4), e1169-e1177. https:// doi.org/10.1542/peds.2006-0815.

Zhang, H., \& Zhu, C. (2016). A study of digital media literacy of the 5th and 6th grade primary students in beijing. The Asia-Pacific Education Researcher, 25(4), 579-592. https://doi.org/10.1007/s40299-016-0285-2.

Zylka, J., Christoph, G., Kroehne, U., Hartig, J., \& Goldhammer, F. (2015). Moving beyond cognitive elements of ICT literacy: First evidence on the structure of ICT engagement. Computers in Human Behavior, 53, 149-160. https://doi.org/ 10.1016/j.chb.2015.07.008. 